\title{
Avibacterium endocarditidis sp. nov., isolated from valvular endocarditis in chickens
}

\author{
Magne Bisgaard, Jens Peter Christensen, Anders Miki Bojesen \\ and Henrik Christensen
}

Correspondence Henrik Christensen hech@life.ku.dk

\author{
Department of Veterinary Pathobiology, Faculty of Life Science, Copenhagen University, \\ 4 Stigbøjlen, DK-1870 Frederiksberg C, Denmark
}

Within the Pasteurellaceae, two new genera Gallibacterium (Christensen et al., 2003a) and Volucribacter (Christensen et al., 2004) have recently been established within the avian $16 \mathrm{~S}$ rRNA cluster 18 of Olsen et al. (2005). Four named species as well as an unnamed taxon were subsequently transferred to a new genus Avibacterium as Avibacterium gallinarum gen. nov., comb. nov., Avibacterium paragallinarum comb. nov., Avibacterium avium comb. nov., Avibacterium volantium comb. nov. and Avibacterium species A (Blackall et al., 2005). While all of the named species of Avibacterium are routinely encountered in the investigation of upper respiratory tract diseases in birds, only Avibacterium paragallinarum is regarded as a primary pathogen, being the causative agent of infectious coryza

The GenBank/EMBL/DDBJ accession number for the 16S rRNA gene sequence of strain $20186 \mathrm{H} 4 \mathrm{H}^{\top}{ }^{\top}$ is $\mathrm{DQ} 465412$, and those for the recN sequences of strain $20186 \mathrm{H} 4 \mathrm{H}^{\top}{ }^{\top}, A$. volantium NCTC $3438^{\top}, A$. paragallinarum NCTC $11296^{\top}$ and Avibacterium sp. A strain CCUG 18782 are DQ899746-DQ899749, respectively.

PFGE results and a recN sequence-based maximum-likelihood tree are available as supplementary material with the online version of this paper. of chickens (Blackall, 1999). Avibacterium avium, Avibacterium volantium and Avibacterium sp. A are normally regarded as part of the commensal microbiota of the upper respiratory tract of chickens and other birds, but are occasionally implicated in various pathologies (Hinz, 1980; Hinz \& Kunjara, 1977; Mutters et al., 1985; Bisgaard, 1993). The only species of Avibacterium involved in systemic infections in addition to upper respiratory tract infections seems to be Avibacterium gallinarum, affecting gallinaceous birds (Christensen et al., 2002a; Bisgaard et al., 2005). In one report, Avibacterium paragallinarum has been isolated from lung, kidney and liver, probably related to systemic infection (Sandoval et al., 1994). A novel non$\mathrm{V}$-factor-requiring group of the Pasteurellaceae showing phenotypic characters similar to those of Avibacterium and tentatively named taxon 50 was recently isolated from valvular endocarditis and septicaemia in broiler parents (M. Bisgaard, unpublished data). Based on phenotypic and genotypic data including PFGE and sequencing of $16 \mathrm{~S}$ rRNA and recN genes, we propose to accommodate taxon 50 within the genus Avibacterium as a separate species. 


\section{Bacterial strains and growth conditions}

A total of 27 isolates from 22 adult broiler parents of the same flock were sampled over a period of 10 weeks and characterized. Twenty isolates were obtained from valvular endocarditis. Eighteen were recorded during production, while two cases were recorded among dead hens left in the house after collection of birds for slaughtering. Two birds with endocarditis allowed two isolates from the liver and two isolates from the spleen to be investigated. Finally, two isolates were obtained from degenerative arthritis and a single isolate originated from chronic adhesive pericarditis of birds without valvular endocarditis (M. Bisgaard, unpublished data). All isolates were grown aerobically on $5 \%$ bovine blood agar (blood agar base, CM 55; Oxoid) at $37^{\circ} \mathrm{C}$ unless otherwise stated.

\section{Phenotypic characterization}

Classical phenotypic tests were performed as reported previously (Bisgaard et al., 1991). Additional characterization included API 20NE tests, which were carried out according to the recommendations of the manufacturer (bioMérieux).

All 27 isolates tentatively classified as taxon 50 were Gramnegative, non-motile, pleomorphic rods that were catalaseand oxidase-positive and produced acid from glucose without gas in Hugh \& Leifson's medium. Haemolysis of bovine red-blood cells was negative and symbiotic growth was not observed. Negative reactions were also observed in Simmons' citrate, mucate, malonate, methyl red and Voges-Proskauer tests, production of $\mathrm{H}_{2} \mathrm{~S}$ in triple sugar iron (TSI) medium, KCN growth, urease, arginine dihydrolase, lysine and ornithine decarboxylases, phenylalanine deaminase, indole, gelatinase and hydrolysis of Tweens 20 and 80. Growth was not observed on MacConkey agar. All isolates were alanine aminopeptidase-positive and reduced nitrate without gas production. Aerobic growth without pigment formation was observed on agar. The porphyrin and phosphatase tests were positive. All isolates produced acid from glycerol, (-)-D-ribose, (-)-D-mannitol, (-)-Dsorbitol, (-)-D-fructose, (+)-D-galactose, (+)-D-glucose, $(+)$-D-mannose, maltose, sucrose, trehalose, raffinose and dextrin. Late production of acid from (+)-D-xylose and inositol might be observed, since these reactions were inconsistent with the strains tested. No acid was produced by any isolate from meso-erythritol, adonitol, (+)-Darabitol, xylitol, $(+)$-L-arabinose, $(-)$-D-arabinose, $(-)$-Lxylose, dulcitol, (+ )-D-fucose, (-)-L-fucose, (+ )-L-rhamnose, (-)-L-sorbose, cellobiose, lactose, $(+)$-D-melibiose, $(+)$-D-melezitose, $(+)$-D-glycogen, inulin, aesculin, amygdalin, arbutin, gentiobiose, salicin or $(+)$-D-turanose. All isolates were ONPG- $(\beta$-galactosidase $)$ and PNPG- $(\alpha-$ glucosidase) positive and NPG- ( $\beta$-glucosidase), ONPF( $\alpha$-fucosidase), ONPX- ( $\beta$-xylosidase), PGUA- ( $\beta$-glucuronidase), $\alpha$-galactosidase- and $\alpha$-mannosidase-negative.

In addition to confirming reactions for oxidase, indole, arginine dihydrolase, urease, hydrolysis of gelatin, $\beta$-glucosidase and $\beta$-galactosidase, API 20NE showed that all isolates of taxon 50 did not reduce nitrates to nitrogen and were unable to assimilate arabinose, caprate, adipate, citrate or phenylacetate, while glucose, mannose, mannitol, $\mathrm{N}$-acetylglucosamine, maltose, gluconate and malate were assimilated.

Key characters that separate taxon 50 from other taxa within the genus Avibacterium are given in Table 1. From three to nine phenotypic characters separate taxon 50 from previously reported taxa of Avibacterium. The closest relationship was observed for Avibacterium gallinarum which, however, can be separated from taxon 50 by acid production from (-)-D-mannitol, (-)-D-sorbitol and (-)L-fucose. Phenotypic characters that separate the genus Avibacterium from other genera of the Pasteurellaceae were recently published by Blackall et al. (2005).

\section{Pulsed field gel electrophoresis (PFGE)}

PFGE using SmaI and XbaI for digestion of DNA was performed as reported previously (Ojeniyi et al., 1991; Christensen et al., 2003a; Chadfield et al., 2007). The size marker N0350S (New England Biolabs) was used for comparison. All isolates of taxon 50 shared the same PFGE type (Supplementary Fig. S1 available in IJSEM Online), indicative of a clonal outbreak of valvular endocarditis. However, since the isolates reported represent the first and only isolates described, additional isolates are needed to allow comments on the genetic diversity of this novel taxon of the Pasteurellaceae. The type strain of Avibacterium gallinarum showed a divergent $\mathrm{XbaI}$ profile, sharing only two bands with taxon 50 (Supplementary Fig. S1).

All 27 isolates were isolated from the same flock over a period of 10 weeks and shared a common phenotype and genotype. To describe a novel species, greater diversity would have been desirable (Christensen et al., 2007). However, the minimal standards for description of novel taxa of the Pasteurellaceae recommend naming of species of particular pathogenic importance irrespective of whether they cover geographical and ecological diversity (Christensen et al., 2007). By doing so, type strains are also made available to the public for further characterization, including investigations of mechanisms of pathogenicity.

\section{$16 S$ rRNA gene sequencing}

$16 \mathrm{~S}$ rRNA gene sequencing of strain $20186 \mathrm{H}_{4} \mathrm{H}^{\mathrm{T}}$ was performed as reported previously (Angen et al., 2003; Christensen et al., 2002b). BLAST searching (Altschul et al., 1997) in GenBank (Benson et al., 2006) showed that no other sequences had been deposited with high similarity to strain $20186 \mathrm{H} 4 \mathrm{H} 1^{\mathrm{T}}$. Pairwise comparisons for similarity were performed by the program WATER included in EMBOSS (Rice et al., 2000). The 16S rRNA gene sequence for strain $20186 \mathrm{H} 4 \mathrm{H} 1^{\mathrm{T}}$ was obtained in the region covering Escherichia coli positions 194-1412. 
Table 1. Key characters for separation of taxa within the genus Avibacterium Blackall et al. 2005

Taxa: 1, Avibacterium gallinarum (data from Bisgaard et al., 2005; Christensen et al., 2002a); 2, Avibacterium paragallinarum biovar 1 (Blackall \& Reid, 1982; Hinz, 1980); 3, Avibacterium paragallinarum biovar 2 (Blackall et al., 2005); 4, Avibacterium avium (Mutters et al., 1985); 5, Avibacterium volantium (Mutters et al., 1985); 6, Avibacterium endocarditidis sp. nov. (Bisgaard taxon 50) (data from this study); 7, Avibacterium sp. A (Mutters et al., 1985). Characters are scored as:,$+ 90 \%$ or more of strains positive within $1-2$ days; $(+), 90 \%$ or more strains positive within 3-14 days; d, 11-89\% of strains positive within 14 days; w, weakly positive within 14 days; -, less than $10 \%$ of strains positive within 14 days; ND, no data.

\begin{tabular}{|c|c|c|c|c|c|c|c|}
\hline Test & 1 & 2 & 3 & 4 & 5 & 6 & 7 \\
\hline Catalase & + & - & - & + & + & + & + \\
\hline Symbiotic growth & - & + & - & + & + & - & + \\
\hline Aerobic growth on agar & + & - & + & + & + & + & + \\
\hline Pigment, yellow & - & - & - & $\mathrm{d}$ & $\mathrm{d}$ & - & d \\
\hline \multicolumn{8}{|l|}{ Acid from: } \\
\hline Glycerol & $\mathrm{d}$ & - & - & ND & - & $(+)$ & - \\
\hline Xylitol & - & - & - & $\mathrm{ND}$ & - & - & $(+)$ \\
\hline$(+)$-L-Arabinose & - & - & - & - & - & - & + \\
\hline (-)-D-Mannitol & - & $+/(+)$ & $+/(+)$ & - & + & + & $\mathrm{d}$ \\
\hline (-)-D-Sorbitol & - & $\mathrm{d}$ & $+/(+)$ & - & $\mathrm{d}$ & + & - \\
\hline$(-)$-L-Fucose & $\mathrm{w} /(+)$ & - & $\mathrm{w} /(+)$ & ND & $(+)$ & - & - \\
\hline$(+)$-D-Galactose & + & - & - & + & + & $(+)$ & + \\
\hline ONPG ( $\beta$-galactosidase $)$ & $\mathrm{d}$ & - & - & - & + & + & d \\
\hline Maltose & + & $(+)$ & - & - & + & + & d \\
\hline Trehalose & + & - & - & + & + & + & + \\
\hline Raffinose & $\mathrm{w} /(+)$ & - & - & ND & - & $(+)$ & $(+)$ \\
\hline Dextrin & + & $\mathrm{w} /(+)$ & - & + & + & + & - \\
\hline PNPG ( $\alpha$-glucosidase) & + & - & - & + & + & + & + \\
\hline
\end{tabular}

The highest 16S rRNA gene sequence similarity between this strain and other taxa of the Pasteurellaceae was obtained to species of Avibacterium. The highest similarity $(98.4 \%)$ was obtained to strain Modesto, belonging to serogroup C of Avibacterium paragallinarum (GenBank accession no. AY498870). Similarities to other members of Avibacterium ranged between $96.5 \%$, to the type strain of Avibacterium gallinarum (GenBank accession no. M75059), and $97.9 \%$, to strain SA7177 of biovar 2 of Avibacterium paragallinarum (accession no. AY498871) as well as strain CCUG 18782 of Avibacterium sp. A (accession no. M75055). Similarities to strains Wuthe DS 1801/91 (GenBank accession no. AF224311) and CCUG 19808 (accession no. AF224312), closely related to Avibacterium, were 93.6 and $92.1 \%$, respectively. Outside Avibacterium, similarities to the type strains of Volucribacter psittacicida and Volucribacter amazonae were 94 and $93.5 \%$, respectively, and the highest similarity to the taxon 2 and 3 complex of Bisgaard was $93.8 \%$, as observed to the reference strain NCTC 11412 of taxon 3 (GenBank accession no. L06079), while $93.1 \%$ similarity was observed to the type strain of Gallibacterium anatis (accession no. AF228001). The highest similarity outside the avian 16S rRNA cluster (Olsen et al., 2005) was obtained to the type strain of [Pasteurella] caballi, at $95.4 \%$ (GenBank accession no.
AF224291) [brackets around genus names indicate species suggested to be excluded from the respective genera in accordance with the terminology of Mutters et al. (1989)].

A multiple alignment was constructed by CLUSTAL_X (Thompson et al., 1997) and included the region between E. coli positions 194 and 1391 of the $r r n B$ gene, with 1175 positions left after removal of gapped columns and 196 data patterns analysed. Maximum-likelihood analysis including bootstrap analysis was performed by fastDNAml (Olsen et al., 1994; Felsenstein, 1995) run on a Linux 7.2compatible server. The analysis was run with a transition/ transversion ratio of 1.5 .

The phylogenetic analysis shown in Fig. 1 was obtained with 22 sequences selected to include all Avibacterium type strains within the avian 16S rRNA cluster of the Pasteurellaceae (Olsen et al., 2005) and type species of other genera within the Pasteurellaceae. The novel species was found to belong to the monophyletic group including taxa of Avibacterium, confirming the $16 \mathrm{~S}$ rRNA gene sequence similarities. Monophyly for Avibacterium was confirmed in accordance with Christensen et al. (2003b) and Blackall et al. (2005). The low bootstrap value of the group of only $57 \%$ and the lack of documentation of the avian 16S rRNA group (Olsen et al., 2005) was probably related to an 


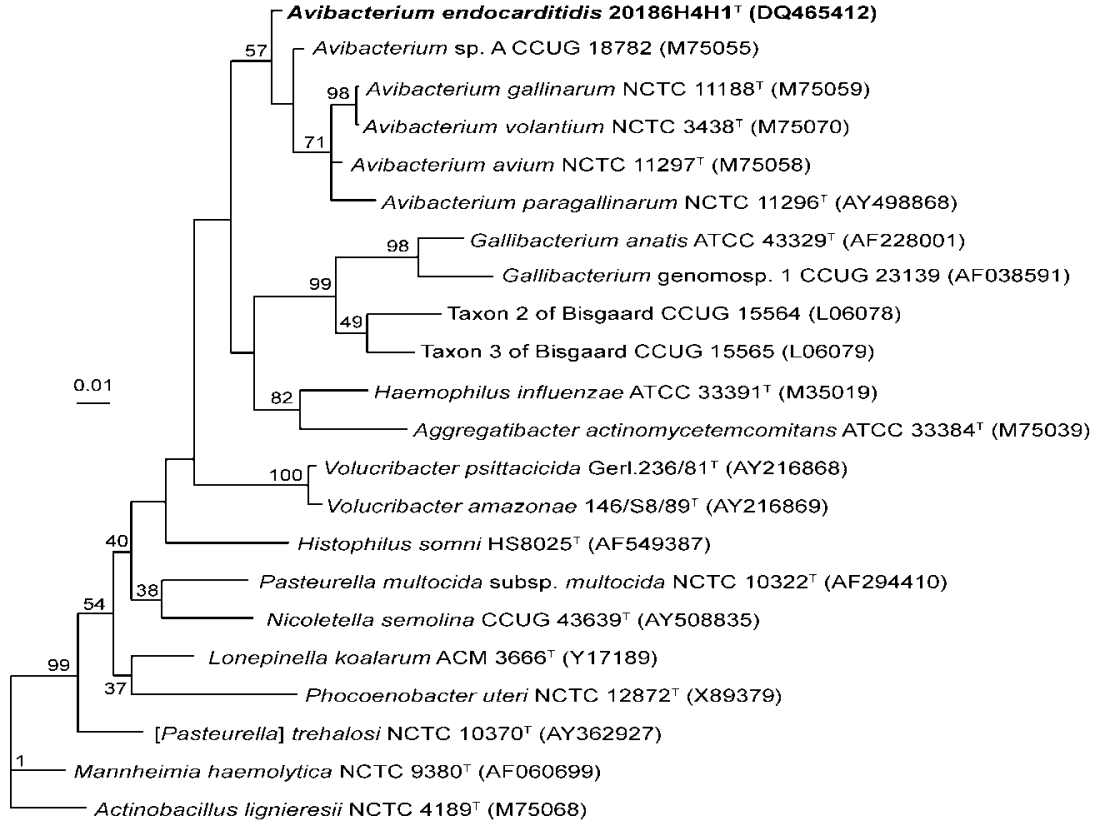

Fig. 1. Phylogenetic relationships between taxon 50 (Avibacterium endocarditidis sp. nov.) and representative members of the Pasteure/laceae with a focus on Avibacterium and related taxa and avian cluster 18 (Olsen et al., 2005) based on maximum-likelihood analysis of $16 \mathrm{~S}$ rRNA gene sequences. Support for monophyletic groups by bootstrap analysis is indicated as numbers out of 100 . The strain in bold has been sequenced in the present investigation. Bar, evolutionary distance of 0.01 (represents sequence variation considering the models for nucleotide substitution and treeshape used in the maximum-likelihood analysis). unbalanced representation of members of the Pasteurellaceae with a focus on only the type strains of type species of genera.

\section{recN sequencing and analysis}

$16 \mathrm{~S}$ rRNA gene sequence analysis is insufficient to separate taxa within Avibacterium (Blackall et al., 2005) and, since the species status of taxon 50 could not be documented unequivocally through 16S rRNA gene sequence comparison, comparison of the recN sequence of $20186 \mathrm{H}_{4} \mathrm{H}_{1}^{\mathrm{T}}$ to those of the type strains of the species of Avibacterium and strain CCUG 18782 of Avibacterium sp. A was performed. Sequencing of strain $20186 \mathrm{H}_{4} \mathrm{H}^{\mathrm{T}}$ (Avibacterium endocarditidis sp. nov.), Avibacterium paragallinarum NCTC $11296^{\mathrm{T}}$, Avibacterium volantium NCTC $3438^{\mathrm{T}}$ and Avibacterium sp. A strain CCUG 18782 was carried out as reported by Kuhnert \& Korczak (2006). In addition to the primers listed by Kuhnert \& Korczak (2006), the sequencing primers $5^{\prime}$-AAAATGCGCAAGCTTTGAGT and 5'ACACGGCGTAAAATACAG were used to determine the $3^{\prime}$ and $5^{\prime}$ regions, respectively, of the $\operatorname{rec} \mathrm{N}$ sequence. DNA sequences were obtained of the region 94-1255 of the $\operatorname{recN}$ gene (numbered according to annotation of the genomic sequence of Pasteurella multocida strain Pm70 deposited under GenBank accession no. AE004439). The type strain of Avibacterium avium did not generate a PCR product with the $r e c N$ primers stated above, indicating significant differences from the other species of Avibacterium, and this species was not included in the analysis. The published sequences of the type strains of Avibacterium gallinarum and Pasteurella multocida and of Volucribacter psittacicida strain 101 were also included in the comparison. The phylogenetic analysis was performed as reported for $16 \mathrm{~S}$ rRNA gene sequences, including 1255 positions and the use of a transition/transversion ratio of 1.1, which was found to maximize the likelihood. The phylogenetic tree shown in Supplementary Fig. S2 shows the unique position of taxon 50 within Avibacterium.

Similarities of 41,84 and $85 \%$ were calculated using the formula for conversion given by Zeigler, (2003) between strain $20186 \mathrm{H} 4 \mathrm{H1}^{\mathrm{T}}$ and the type strains of Avibacterium paragallinarum, Avibacterium gallinarum and Avibacterium volantium, respectively, whereas the similarity to Avibacterium sp. A was $83 \%$. DNA sequence similarity values calculated from recN sequences of 17 strains of Actinobacillus capsulatus representing seven different countries and four continents showed similarities between 94 and $95 \%$ (Kuhnert et al., 2007), while similarity values between different serovars of Actinobacillus pleuropneumoniae varied between 91 and $95 \%$ (Kuhnert \& Korczak, 2006). Comparison of $\mathrm{recN}$ in the present study therefore clearly confirmed the species status of taxon 50 (Avibacterium endocarditidis sp. nov.).

\section{Description of Avibacterium endocarditidis sp. nov.}

Avibacterium endocarditidis (en.do.car.di'ti.dis. N.L. n. endocarditis endocarditis, the medical term for an infection of the inner heart; N.L. gen. n. endocarditidis of endocarditis).

Growth on blood agar is non-symbiotic, isolates forming regular, circular, slightly raised, non-haemolytic colonies with an entire margin. The surface of the colonies is smooth, shiny and opaque with a greyish tinge. Colonies have a diameter of $1.0-1.5 \mathrm{~mm}$ after aerobic incubation for $24 \mathrm{~h}$ at $37^{\circ} \mathrm{C}$. The consistency of the colonies is unguentlike and colonies do not adhere to the agar surface. All 
isolates meet the phenotypic characters for the genus Avibacterium reported previously (Blackall et al., 2005). Catalase is produced. Acid is produced from glycerol, (-)-D-mannitol, (-)-D-sorbitol, (+)-D-galactose, maltose, trehalose, raffinose and dextrin but not from xylitol, $(+)$-L-arabinose or (-)-L-fucose. ONPG and PNPG tests are positive. The characters stated allow separation from other species of Avibacterium. Detailed phenotypic characters for all isolates including the type strain are given under phenotypic characterization.

The type strain, $20186 \mathrm{H} 4 \mathrm{H}^{\mathrm{T}}{ }^{\mathrm{T}}\left(=\mathrm{CCUG} 52860^{\mathrm{T}}=\mathrm{DSM}\right.$ $\left.18224^{\mathrm{T}}\right)$, was isolated from valvular endocarditis of a chicken in Denmark in 2004.

\section{Acknowledgements}

Tony Bønnelycke and Katrine Madsen are thanked for excellent technical assistance. We would like to thank Professor Dr Hans G. Trüper, Rheinische Friedrich-Wilhelms-Universität, Bonn, for help with the Latin name.

\section{References}

Altschul, S. F., Madden, T. L., Schaffer, A. A., Zhang, J., Zhang, Z., Miller, W. \& Lipman, D. J. (1997). Gapped BLAST and PSI-BLAST: a new generation of protein database search programs. Nucleic Acids Res 25, 3389-3402.

Angen, Ø., Ahrens, P., Kuhnert, P., Christensen, H. \& Mutters, R. (2003). Proposal of Histophilus somni gen. nov., sp. nov. for the three species incertae sedis 'Haemophilus somnus', 'Haemophilus agni and 'Histophilus ovis'. Int J Syst Evol Microbiol 53, 1449-1456.

Benson, D. A., Karsch-Mizrachi, I., Lipman, D. J., Ostell, J. \& Wheeler, D. L. (2006). GenBank. Nucleic Acids Res 34, D16-D20.

Bisgaard, M. (1993). Ecology and significance of Pasteurellaceae in animals. Zentralbl Bakteriol 279, 7-26.

Bisgaard, M., Houghton, S. B., Mutters, R. \& Stenzel, A. (1991). Reclassification of German, British and Dutch isolates of so-called Pasteurella multocida obtained from pneumonic calf lungs. Vet Microbiol 26, 115-124.

Bisgaard, M., Christensen, H., Behr, K.-P., Baron, G. \& Christensen, J. P. (2005). Investigations on the clonality of strains of Pasteurella gallinarum obtained from turkeys in Germany. Avian Pathol 34, 106-110.

Blackall, P. J. (1999). Infectious coryza: overview of the disease and new diagnostic options. Clin Microbiol Rev 12, 627-632.

Blackall, P. J. \& Reid, G. G. (1982). Further characterization of Haemophilus paragallinarum and Haemophilus avium. Vet Microbiol 7, 359-367.

Blackall, P. J., Christensen, H., Beckenham, T., Blackall, L. L. \& Bisgaard, M. (2005). Reclassification of Pasteurella gallinarum, [Haemophilus] paragallinarum, Pasteurella avium and Pasteurella volantium as Avibacterium gallinarum gen. nov., comb. nov., Avibacterium paragallinarum comb. nov., Avibacterium avium comb. nov. and Avibacterium volantium comb. nov. Int J Syst Evol Microbiol 55, 353-362.

Chadfield, M. S., Christensen, J. P., Decostere, A., Christensen, H. \& Bisgaard, M. (2007). Geno- and phenotypic diversity of avian isolates of Streptococcus gallolyticus subsp. gallolyticus (Streptococcus bovis) and associated diagnostic problems. J Clin Microbiol 45, 822-827.
Christensen, H., Dziva, F., Olsen, J. E. \& Bisgaard, M. (2002a). Genotypic heterogeneity of Pasteurella gallinarum as shown by ribotyping and 16S rRNA sequencing. Avian Pathol 31, 603-610.

Christensen, H., Bisgaard, M., Angen, Ø. \& Olsen, J. E. (2002b). Final classification of Bisgaard taxon 9 as Actinobacillus arthritidis sp. nov. and recognition of a novel genomospecies for equine strains of Actinobacillus lignieresii. Int J Syst Evol Microbiol 52, 1239-1246.

Christensen, H., Bisgaard, M., Bojesen, A. M., Mutters, R. \& Olsen, J. E. (2003a). Genetic relationships among avian isolates classified as Pasteurella haemolytica, 'Actinobacillus salpingitidis' or Pasteurella anatis with proposal of Gallibacterium anatis gen. nov., comb. nov. and description of additional genomospecies within Gallibacterium gen. nov. Int J Syst Evol Microbiol 53, 275-287.

Christensen, H., Foster, G., Christensen, J. P., Pennycott, T., Olsen, J. E. \& Bisgaard, M. (2003b). Phylogenetic analysis by $16 \mathrm{~S}$ rDNA sequence comparison of avian taxa of Bisgaard and characterization and description of two new taxa of Pasteurellaceae. J Appl Microbiol 95, 354-363.

Christensen, H., Bisgaard, M., Aalbæk, B. \& Olsen, J. E. (2004). Reclassification of Bisgaard taxon 33, with proposal of Volucribacter psittacicida gen. nov., sp. nov. and Volucribacter amazonae sp. nov. as new members of the Pasteurellaceae. Int J Syst Evol Microbiol 54, 813-818.

Christensen, H., Kuhnert, P., Busse, H.-J., Frederiksen, W. C. \& Bisgaard, M. (2007). Proposed minimal standards for the description of genera, species and subspecies of the Pasteurellaceae. Int J Syst Evol Microbiol 57, 166-178.

Felsenstein, J. (1995). PHYLIP (phylogeny inference package) version 3.5c. Department of Genetics, University of Washington, Seattle.

Hinz, K.-H. (1980). Differentiation of Haemophilus paragallinarum and Haemophilus avium by phenotypical characteristics. In Proceedings of the Second International Symposium of Veterinary Laboratory Diagnosticians, vol. 3, pp. 347-350. 24-26 June 1980, Lucerne, Switzerland.

Hinz, K.-H. \& Kunjara, C. (1977). Haemophilus avium, a new species from chickens. Int J Syst Bacteriol 27, 324-329.

Kuhnert, P. \& Korczak, B. M. (2006). Prediction of whole-genome DNA-DNA similarity, determination of $\mathrm{G}+\mathrm{C}$ content and phylogenetic analysis within the family Pasteurellaceae by multilocus sequence analysis (MLSA). Microbiology 152, 2537-2548.

Kuhnert, P., Korczak, B. M., Christensen, H. \& Bisgaard, M. (2007). Emended description of Actinobacillus capsulatus Arseculeratne 1962, $38^{\mathrm{AL}}$. Int J Syst Evol Microbiol 57, 625-632.

Mutters, R., Piechulla, K., Hinz, K.-H. \& Mannheim, W. (1985). Pasteurella avium (Hinz and Kunjara 1977) comb. nov. and Pasteurella volantium sp. nov. Int J Syst Bacteriol 35, 5-9.

Mutters, R., Mannheim, W. \& Bisgaard, M. (1989). Taxonomy of the group. In Pasteurella and Pasteurellosis, pp. 3-34. Edited by C. Adlam \& J. M. Rutter. London: Academic Press.

Ojeniyi, B., Højby, N. \& Rosdahl, V. T. (1991). Genome fingerprinting as a typing method used on polyagglutinable Pseudomonas aeruginosa isolates from cystic fibrosis patients. APMIS 99, 492-498.

Olsen, G. J., Matsuda, H., Hagström, R. \& Overbeek, R. (1994). fastDNAml: a tool for construction of phylogenetic trees of DNA sequences using maximum likelihood. Comput Appl Biosci 10, 41-48.

Olsen, I., Dewhirst, F. E., Paster, B. J. \& Busse, H.-J. (2005). Family I. Pasteurellaceae Pohl 1981b, 382 ${ }^{\mathrm{VP}}$. In Bergey's Manual of Systematic Bacteriology, 2nd edn, vol. 2, part B, pp. 851-856. Edited by D. J. Brenner, N. R. Krieg, J. T. Staley \& G. M. Garrity. Springer: New York.

Rice, P., Longden, I. \& Bleasby, A. (2000). Eмвоss: the European molecular biology open software suite. Trends Genet 16, 276-277. 
Sandoval, V. E., Terzolo, H. R. \& Blackall, P. J. (1994). Complicated infectious coryza outbreaks in Argentina. Avian Dis 38, 672-678.

Thompson, J. D., Gibson, T. J., Plewniak, F., Jeanmougin, F. \& Higgins, D. G. (1997). The CLUSTAL_X windows interface: flexible strategies for multiple sequence alignment aided by quality analysis tools. Nucleic Acids Res 25, 4876-4882.

Zeigler, D. R. (2003). Gene sequences useful for predicting relatedness of whole genomes in bacteria. Int J Syst Evol Microbiol 53, 1893-1900. 